\title{
Why Radicalism is Growing Among Children?
}

\author{
Husnul Isa Harahap ${ }^{1}$, Tengku Irmayani ${ }^{2}$ \\ \{ husnul.harahap@usu.ac.id ${ }^{1}$,Tengku.irmayani@gmail.com² $\}$
}

Department of Political Science, Universitas Sumatera Utara, Medan, Indonesia

\begin{abstract}
On September 1st, 2017, an Indonesian child named Hatf Saiful Rasul was reportedly hit by air strikes in Syria. As a result of the attack, he has been rumored to have died there. His presence in Syria is related to his desire to join ISIS and fight in Syria. As a result of this incident or news, it appears the assumption that children are very vulnerable to exposure to radical ideology. Children need protection so children can avoid from radical ideology. The main question in this study is, why radicalism is growing among children? This study has found four main explanations. First, children are indeed one of the potential targets recruited by radical groups to achieve certain goals. Secondly, information is very accessible, including radical content in cyberspace. Children can access it without being able to filter the information critically. Third, the use of religious teachings as a method to attract sympathy. Fourth, environmental influence and compulsion. The research technique used in this study is qualitative. The data used in this study is secondary data (literature study and document).
\end{abstract}

Keywords: radicalism, terrorism, ideology, de-radicalization.

\section{Introduction}

Is it possible for the children to become terrorists? It is easy to answer but difficult to prove question especially for cases in Indonesia in the past. However, nowadays there are several cases where children have joined terrorist organization. It proves that children are possible to join in an organization or terrorist group. One of the most surprising cases is the phenomenon of Hatf Saiful Rasul. Hatf Saiful Rasul was a boy who joined the Islamic State of Iraq and Syria's Group (ISIS) in Syria. He was about 11 years old. On September, Hatf Saiful Rasul reported to be died in Syria. He was stoked off by an air strike.

This case has become an interesting case due to three things. Firstly, Hatf was very young. Secondly, he had a high spirit to go to Syria. According to his father's confession, he has expressed his desire several time to go Syria. Thirdly, He took off his school days to became an ISIS fighter. In Syria, He became an ISIS fighter and joined the French's group fighter. In other words, even if Hatf is a child, but his sincerity was so different compared to other children in general.

Aside from Hatf's case, there are other cases where children became radical. There are some children in Indonesia involved in terrorism. For example, a terror case in Samarinda (East Kalimantan Province) in 2016. This incident has raised questions about the relationship between children and radical ideology. Why the case of children affected by radical ideology always happen? The main question in this study is, why radicalism is growing among children? Admittedly this phenomenon has been happening long enough in some countries. However, an explanation of this is still needed - especially in-depth analysis. 
There are three reasons why this study is important. First, several incidents about radicalism indicated there was a special pattern. Children have gained an easy access to radicalism. Second, children are known to be radicalized after a terrorist acted or joined a terrorist's organization. It has indicated there is no effective way to detect children who have a radical ideology. Third, there is no effective way to prevent the process of radicalization among children. Especially in cases of radicalization without direct contact with a terrorist or radical's group.

\section{Method}

Method of this study is qualitative. The data used in this study are secondary data. Data are obtained from news and documents which are available online. Qualitative analysis is used for data analysis.

\section{The case of Children Victim of radical Ideology}

The last three years (2016-2018) there was some news where children involved or engaged in radical acts. The latest case was a bomb case that happened in Surabaya (Mei, 13 ${ }^{\text {th }} 2018$ ). Head of Public Relations of Indonesia Police Irjen Setyo Wasisto said a phenomenon of involvement of children in the case of terror in Surabaya as a victim. Head of Public Relations of Indonesia Police Irjen Setyo Wasisto said "kita agak susah mendeteksi karena sebenarnya mereka ini adalah korban. Anak-anak ini adalah korban" [sic.] [1] ["We feel it is little hard to detect because they are the victims. These children are victims".

In Surabaya's case, four children are involved in this terror act. Two were boys, and the other two were girls. According to the explanation of National Police Chief Gen. Tito Karnavian “Anak perempuannya bernama FS berumur 12 tahun dan PA berumur sembilan tahun" [sic] [2] ["The girls' initial are FS, 12 years old and PA, 9 years old"]. A self-explosion action was carried out by the mother of both children.

In 2017, cases of child victims of radical ideology occurred in children aged 11 years. The child involved in the case named Hatf Saiful Rasul. According to detik.com, He died on September $1^{\text {st }}, 2016$ [3]. However, the news spread in Indonesia in 2017. Hatf left to Syria in 2015 at the age of 11 years [4]. Joined to Islamic State of Iraq and Syria (ISIS) to fight in Syria.

The case of acts of terror that occurred in 2016 was a case of Church attack in Medan City, North Sumatra Province. Aside from that case, the case of terror happened in the Church of Oikumene Sengkotek Samarinda, East Kalimantan Province. Each occurred in August and November 2016.

\section{Potential Targets and Vulnerable are Provoked}

There are many kinds of deviant acts committed by adults as well as children. However, actions that are influenced by radical ideology have their characteristics. Children acted based on this ideology. Formed by process of the doctrinaire and have ideological responsibilities and missions. The analysis of this study describe the phenomenon in which children are affected by 
radical ideology. Some ended with death and some were punished through court decisions. Others hope to return to normal life.

The analysis in this study explains that there are four reasons why children are exposed to radical ideology. First, children have become one of the potential targets recruited by radical ideology groups. There are even cases where the parents of the children played a role in educating their children to have radical ideologies. For example a very clear case is the Hatf's case. Hatf left to Syria with his uncle and aunt to join the ISIS fighters. According to Syaiful Anam Said or known by the name Brekele (Father of Hatf Saiful Rasul), Hatf had long desired to go to Syria. Brekele did not prohibit but supported it. The family also supported. In his confession Brekele said “...Alhamdulillah, sebenarnya Abi (Brekele) juga sangat menginginkan Hatf berangkat, hanya Abi belum yakin apakah Hatf siap atau tidak. Maka saat itu Hatf sendiri yang meminta, apalagi Ummi juga setuju, urusannya jadi lebih mudah..." [sic.] [5] [“...Alhamdulillah, in fact Abi (Brekele) also desperately wanted Hatf to leave, but Abi was not sure whether Hatf was ready or not. So then Hatf himself who asked, moreover, Ummi also agreed, everything becomes easier...”].

Beside Hatf, there are also other children who left to Syria to joined ISIS. The question is, why do children become potential targets? Answer to this question is very simple. According to David H. Gray and Tom Owen Matchin III, children are easily indoctrinated [6]. In Hatf's case, his parents felt proud because his son fought in Syria. Although his son has been dead by air strike, regarding the news of his dead son, Syaiful Anam said "I do not feel sad or loss, except a limited sadness as a father who was left by his beloved child...Instead, I felt happy because my child has achieved martyrdom, inshallah..." [7].

Secondly, information is very accessible - there is no exception for radical content, especially in cyberspace. Children can access it without being able to filter information critically. Ivan's case is an example. Ivan is 18 years old. Some people call the action as "lone wolf" or "self-radicalization" [8]. He committed a terror alone. Under the influence of ISIS's ideology, but he never tied to the ISIS network. The influence is gained through cyberspace. Coordinating Minister for Political, Legal and Security Affairs at the time, Wiranto said that "Sehari-hari dia aktif di warnet itu, belajar dan mencari informasi. Dia terinspirasi kelompok garis keras dari internet, lalu dia belajar mengemas bom dari internet... " [sic.] [9] ["Every day he is actively goes to the internet cafe, learns and seeks for information. He was inspired by hardliners from the internet, then he learned to create bombs from the internet ..."]. The case of Ivan is a case where he carried out a suicide bombing but failed. The action was conducted at St. Joseph Catholic Church in Medan. Precisely on August 28 ${ }^{\text {th }}, 2016$, around 8:00 am.

ISIS is based in Iraq and Syria. Nevertheless, its influence persists in various countries in both were developed and developing countries. Such a significant influence as the impact of propaganda content spread over the internet. According to The New York Times, in America, the influence of ISIS is spread over the internet, is quite worrying. The New York Times notes that "Through January this year, at least 100 Americans were thought to have traveled to join jihadists in Syria and Iraq, among nearly 4,000 Westerners who had done so" [10].

In Indonesia, Ivan was an exemplary case of the impact of ISIS propaganda on the internet. Based on that fact Wiranto (Coordinating Minister for Political, Legal and Security Affairs) warned that parents need to remind their children about misleading internet content. Wiranto refers to the case of Ivan who has "...dari internet, karena kakaknya punya warnet... hasil cuplikan di internetnya tentang ISIS ... Ini alert buat orang tua bagaimana bisa awasi anaknya, sehingga tak terus dicekoki berita di internet yang menyesatkan, sehingga mereka terobsesi..." [sic.] [11] ["...from the internet, because his sister has an internet cafe ... the results of his 
internet footage about ISIS ... This alert for parents on how can supervise their children not to be kept fed with news on the internet that are misleading, so they are obsessed ..."'].

Third, the use of religious teachings as a method to attract sympathy. Two of the seven suspects in the Molotov cocktail attack in Samarinda were children. Each is 15 and 16 years old. The attack was carried out against the Sikotus Church of Sengkotek Samarinda, East Kalimantan Province. This incident occurred on November 13, 2016. According to Head of Public Relations of the East Kalimantan Regional Police Senior Commissioner Fajar Setiawan, the involvement of these children related to religious doctrine. Fajar Setiawan reminded that "...pada masa remaja, anak-anak rentan dengan doktrin-doktrin berbahaya..." [sic.] [12] [...in adolescence, children are vulnerable to dangerous doctrines ..."].

Religion teaches to do good. However, some compilations of religious interpretations are used for the benefit of radical groups. Children receive these religious teachings and record radical messages in their minds. As a result, children are affected by radical ideology. This will be even more worrying if children absorb the lesson as a way of life, as a way of acting and acting radically.

Fourth, environmental influence and compulsion. The case of Hatf Saiful Rasul can also be categorized as a case of radical children because of the influence of the environment. He was born and raised by his father in a query environment of Densus 88 (special anti-terrorist forces). His father's friends raised him (other terrorists like Daeng Koro alias Sabar, Abu Wardah (killed in Syria), Abu Uswah alias Qodir, and Hasan). He once lived in the village of Mujahidin (Pandajaya) in Poso. He followed his father to move around to hide. He attended his father's preferred school at Ibnu Mas'ud Pesantren Suka Jaya Village, Bogor Regency. Twelve of these pesantren students were reportedly arrested in Singapore for going to Syria [13]. So, the environment in which Khatf grew up was an effective vessel that nurtured the development of radical ideology in him.

However, the case of Hatf Saiful Rasul is not an appropriate example for the case of compulsion". In Indonesia case of compulsion have never occurred. But this case can be seen clearly in other countries. For example in the eastern region of Chad State bordering Sudan. Children are forced and kidnapped to fight. Erwin van der Borght (Program Director of African Amnesty International) said "...kejadian bahwa ribuan anak harus kehilangan masa kanakkanaknya dan dipaksa oleh sejumlah orang dewasa untuk bertempur dalam perang mereka adalah sesuatu hal yang tragis..." [sic.] [14] ["...the event that thousands of children must lose their childhood and be forced by a number of adults to fight in wars are tragic..."]. The case of children forced to fight also occurred in Syria. The acknowledgment of the child in BBC New noted said "...mereka mencuci otak saya. Buku-buku mereka seperti sihir. Cepat sekali mengubah pikiran kita. Saya berani taruhan, bukan cuma saya. Bahkan pikiran orang dewasa pasti juga bisa berubah kalau membaca buku-buku itu..." [sic.] [15] [“...they brainwash me, their books are like magic, it changed our minds quickly, I bet I'm not the only one, even the adult minds can also change when reading those books..."]. They are forced to become ISIS warriors.

\section{Conclusion}

The case of children absorbing radical ideology in Indonesia is a new phenomenon. The data described that cases like this continue to increase in number. The main question in this study is, why radicalism is growing among children? This study has found four main 
explanations. First, children are indeed one of the potential targets recruited by radical groups to achieve certain goals. Secondly, information is very accessible, such as radical content in cyberspace. Children can access it without being able to filter the information critically. Third, the use of religious teachings as a method to attract sympathy. Fourth, environmental influence and compulsion. This study reinforces the theory of David H. Gray and Tom Owen Matchin III that asserts that children are easily indoctrinated.

\section{Acknowledgment}

Penelitian ini di biayai oleh Universitas Sumatera Utara Sesuai dengan Kontrak Pelaksanaan Penelitian TALENTA Universitas Sumatera Utara Tahun Anggaran 2018 Nomor: 2590/UN5.1.R/PPM/2018 Tanggal 16 Maret 2018 [sic.] [This publication was funded by the Universitas Sumatera Utara (USU) in accordance with the Talenta Research Contract Universitas Sumatera Utara (2018)].

\section{References}

[1] Setiawan, S. R. D. “Anak-anak Terlibat dalam Aksi Bom, Polri Menilai Mereka adalah Korban,” Kompas.com, 18-May-2018.

[2] "Satu keluarga di balik bom Surabaya: Kapolri minta Presiden terbitkan Perpu antiterorisme," bbc.com, 13-May-2018.

[3] Damarjati,D. "Jadi Petarung ISIS, Bocah Asal Indonesia Tewas," detik.com, 10-Sep-2017.

[4] Nugroho, F. S. Tran., "Kisah Hatf Saiful Rasul, Bocah 13 Tahun Asal Bogor yang Pergi Ke Suriah \& Bergabung dengan ISIS," tribun.com, 18-May-2018.

[5] "Kisah Tragis Tewasnya Anak Brekele di Suriah," detikX.

[6] Gray, D. H., and Matchin III Tom Owen, "Children: The New Face of Terrorism," International NGO Journal, vol. 3, no. 6, pp. 108-114, Jun. 2008.

[7] Allard, T. "Indonesian School a Launchpad for Child Fighters in Syria's Islamic State," Reuters, 07-Sep-2017.

[8] "Kapolri Tito: Teror Bom Medan Fenomena Baru, Lone Wolf," Tempo.co, 05-Sep-2016.

[9] “Teroris Medan Kegoda Duit 10 Juta," Harian Rakyat Merdeka, 30-Aug-2016.

[10] Callimachi, R. "ISIS and the Lonely Young American," The New York Times, 27-Jun-2015.

[11] Tuwo, A. G. "Wiranto: Bomber Medan Belajar Rakit Peledak dari Internet," Liputan6.com, 29Aug-2016.

[12] Nara, G. "Dua Tersangka Kasus Bom Molotov adalah Anak di Bawah Umur," Kompas.com, 21Nov-2016.

[13] "Jejak Hatf, Dari Poso Hingga Suriah," detikX, 14-Sep-2017.

[14] "Chad Rekrut Anak-anak sebagai Tentara," BBC, 10-Feb-2011.

[15] “Anak-anak yang Dipaksa untuk Berperang oleh ISIS,” BBC, 21-Mar-2017. 